\title{
Käyttäytymistieteelliset teoriat ja laadulliset menetelmät interventioiden tukena
}

Oman käyttäytymisen muuttaminen ei ole helppoa. Ei edes silloin, kun tiedämme muutoksen olevan välttämätöntä, tai kun kovasti toivoisimme pystyvämme siihen. Vielä vaikeampaa muutos on silloin, kun haluamme vaikuttaa siihen, miten toiset ihmiset käyttäytyvät. Tällaisia tilanteita voi tulla eteemme esimerkiksi lasten kasvatukseen, terveysneuvontaan tai esimiestyöhön liittyen.

Miten muutosta sitten kannattaisi edistää? Ensin on hyvä tunnistaa, mikä on se käyttäytyminen, johon toivomme muutosta. Kenties haluamme elämäämme jotakin lisää, kuten enemmän yhteistä aikaa perheen kanssa. Tai sitten haluamme siitä jotain pois, kuten tupakoinnin. Voimme myös haluta tehdä joitakin tuttuja asioita uudella tavalla: vaikkapa alkaa kulkea töihin kävellen tai pyörällä. Keinot, joiden tiedämme olevan tehokkaita ajan hallinnassa, eivät välttämättä sovi yhtä hyvin haitallisesta tottumuksesta eroon pääsemiseen. Tupakoinnin lopettaminen vaatii itsekontrollia ja epäterveellisen käyttäytymisen välttämistä, kun taas pyöräilyn lisääminen edellyttää aktiivista pyrkimystä haluttua päämäärää kohti - ja perheen kanssa vietetyn ajan lisääminen niitä molempia, eli sekä itsekontrollia että aktiivista toimintaa.

Muutoksen aikaansaaminen on vaikeaa, koska käyttäytymiseemme vaikuttaa useita samanaikaisia ja eri tasoisia tekijöitä. Yksi tapa hahmottaa näiden tekijöiden moninaisuutta on tarkastella erikseen ihmistä yksilönä, hänen välitöntä sosiaalista ja fyysistä ympäristöään sekä yhteiskunnassa vaikuttavia rakenteellisia tekijöitä $(1,2)$. Jos lähin koulu sijaitsee esimerkiksi parinkymmenen kilometrin päässä, matka voi olla sekä liian pitkä että liian vaarallinen lapsen pyöräiltäväksi. Jos taas itse haluaisit lopettaa tupakoinnin, mutta puolisosi ja ystäväsi eivät halua, saattaa savuton elämäntapa jäädä vain lyhytaikaiseksi kokeiluksi. Käyttäytymisen muutokseen pyrittäessä onkin olennaista tarkastella paitsi yksittäisen ihmisen tekoja ja valintoja, myös niitä olosuhteita, joissa hän elää.

Kun eri väestöryhmien käyttäytymistä pyritään muuttamaan erilaisten interventioiden ja ohjelmien avulla, kannattaa toimintaa suunniteltaessa käyttää hyödyksi sekä käytännön kokemukseen perustuvaa että tieteellistä tietoa. Kohderyhmään tutustuminen sekä muutosten ja kokemusten ymmärtäminen ohjelman kehittämisja pilotointivaiheessa on omiaan syöttämään tietoa itse intervention suunnitteluun. Kohderyhmään kuuluvien henkilöiden lisäksi suunnitteluryhmään on hyvä kutsua kontekstia tuntevia tahoja. Laajan osallistamisen avulla pystytään paitsi huomioimaan kohderyhmän tarpeet ja olosuhteet, myös määrittelemään tarkasti, mikä on se ongelma, johon halutaan vaikuttaa, mitkä ovat ongelmakäyttäytymisen syyt sekä yksilön että ympäristön tasolla ja millaiseen lopputulemaan ohjelmalla pyritään. (3.) Se, että tiedämme, miksi tupakointi aloitetaan ja miksi siitä on hankala luopua, ei kuitenkaan riitä varmistamaan uudenlaisen elämäntavan toteutumista. On hahmotettava, millaisilla keinoilla haluttu muutos voidaan saada aikaan - ja tässä käyttäytymistieteelliset teoriat voivat olla avuksi (4).

Teoriaperusteisten muutosohjelmien on osoitettu onnistuvan käyttäytymisen muutoksessa paremmin kuin niiden ohjelmien, joiden suunnittelussa ei ole hyödynnetty teoriaa. Koska käyttäytymisen muutokseen liittyviä teorioita on useita, kannattaa aluksi pohtia, mikä on se asia, jonka halutaan muuttuvan, ja millaisen muutospolun kautta tämän asian ajatellaan muuttuvan. Tavoitteena voi olla esimerkiksi pyrkiä ensin muuttamaan yksilöiden käyttäytymistä ja ajatella muutoksen sitä kautta etenevän yhteisöjen ja ryhmien toimintaan, tai tehdä ensin muutoksia ympäristöön ja ajatella olosuhteiden muutoksen muo- 
vaavan yksilöiden käyttäytymistä. Hyödyllinen viitekehys tässä pohdinnassa on COM-B-malli, jossa käyttäytymisen muutoksen ajatellaan edellyttävän sekä kyvykkyyttä, motivaatiota että mahdollisuuksia toteuttaa halutunlaista käyttäytymistä. Teoria auttaa tunnistamaan niitä asioita, joihin ohjelmalla voidaan vaikuttaa tietyssä kohderyhmässä, tietyssä ympäristössä ja tietyn käyttäytymisen suhteen. $(5,6$.) Esimerkiksi lasten ja nuorten liikunnan edistämisessä toimenpiteet kannattaa valita sen mukaan, halutaanko liikuntaa lisätä vapaa-aikaan, koulupäivään vai molempiin (3).

Käyttäytymistä voidaan säädellä sekä tietoisten ponnistelujen että automaattisten prosessien kautta. Tottumusten automatisointi on helpompaa silloin, kun lähiympäristö tarjoaa siihen riittävästi tilaisuuksia. (6.) Esimerkiksi pitkäaikaisen istumisen haittoja on mahdollista vähentää tuomalla luokkiin seisomapöytiä, jumppapalloja ja istumatyynyjä sekä rohkaisemalla opiskelijoita niiden käyttöön. Opettamalla sellaisia taitoja, joilla omaa käyttäytymistä voidaan johtaa, kuten suunnittelua, omaseurantaa ja esteiden hallintaa, voidaan puolestaan vahvistaa kyvykkyyttä muuttaa haluttu käyttäytyminen, kuten vapaa-ajan liikunnan lisääminen, uudeksi tavaksi toimia. (3.) Myös motivaatioon vaikuttavat sekä tietoiset prosessit että sosiaalinen ympäristö. On todettu, että elintapamuutosten onnistumista edesauttaa se, että ohjaajien vuorovaikutustyyli vahvistaa asiakkaiden autonomian tunnetta ja että muutokseen saa tukea itselle tärkeiltä ihmisiltä (7). Itsemääräämisteorian (Self-Determination Theory, $S D T)$ mukaan tällaiset asiat vahvistavat sisäistä motivaatiota, joka puolestaan varmistaa muutoksen ylläpitämistä pitkällä aikavälillä (8).

Vanhimpia muutosohjelmien kehittämisessä hyödynnettyjä teorioita ovat erilaiset yksilönsisäisiin tekijöihin, kuten arvostuksiin, uskomuksiin ja odotuksiin liittyvät mallit. Terveysuskomusmallin (Health Belief Model, HBM) mukaan tieto nykyisen, terveydelle vahingollisen käyttäytymisen seurauksista on riittävä muuttamaan käyttäytymistä silloin, kun yksilö kokee seurausten olevan vakavia ja muutoksen hyötyjen sen haittoja suurempia. Terveyskäyttäytymisen prosessimalli (Health Action Process Approach, HAPA) korostaa, että aikomus käyttäytymisen muutokseen syntyy vasta, kun yksilö uskoo siihen, että hän pystyy muuttamaan käyttäyty- mistään tavoitteen mukaiseksi. Perustellun toiminnan lähestymistapa (Reasoned Action Approach, $R A A$ ) huomioi odotusten ja uskomusten taustalla olevat sosiaaliset vaikutteet eli normit. Normeihin sisältyy sekä se, mitä yksilö uskoo muiden odottavan häneltä, että se, millä tavalla hän uskoo muiden vastaavassa tilanteessa käyttäytyvän. (8.)

Sillä, millaisiin sosiaalisiin ryhmiin samaistumme, millaisena itseämme pidämme ja millainen haluaisimme olla, on merkitystä myös käyttäytymisen muutoksen kannalta $(9,10)$. On huomattava, että johonkin ryhmään samaistuminen ei välttämättä edellytä siihen kuulumista, vaan voi tapahtua vaikkapa vain sosiaalista mediaa seuraamalla. Epävarmuus haluttuun ryhmään kuulumisesta voi saada nuoren omaksumaan haitallisia tapoja, kuten nuuskan käytön, jos nuuskaaminen on kyseisessä ryhmässä yleinen ja hyväksytty käytäntö. Samalla tavalla esimerkiksi muuton tai koulun vaihdon mukanaan tuoma uusi kaveripiiri saattaa innostaa hänet käymään säännöllisesti kuntosalilla.

Yhteisen maailmankuvan, jaettujen merkitysten ja ryhmän omaksumien normien voidaan ajatella olevan tietynlainen sosiaalinen maailma, johon erilaiset yksilöt osallistuvat enemmän tai vähemmän intensiivisesti. Mitä tiiviimmin tuossa maailmassa ollaan mukana, sen tärkeämmäksi nämä merkitykset tulevat. Myös liikunta voidaan käsitteellistää tällä tavalla omaksi sosiaaliseksi maailmakseen, jossa osallisuuden astetta määrittää sekä tieto liikunnasta että se, kuinka läheinen ja tärkeä liikunnan maailma itselle on. (11.) Kaksi eri ihmistä saattaa esimerkiksi käydä kuntosalilla yhtä säännöllisesti ja tehdä yhtä monta samanlaista harjoitusta, mutta heidän suhtautumisensa tähän lajiin ei välttämättä ole samanlainen. Kun toiselle riittää oman kunto-ohjelman läpivieminen, toinen saattaa sen lisäksi seurata omaa kehittymistään merkitsemällä tuloksiaan muistiin ja hankkia aktiivisesti tietoa esimerkiksi siitä, millä tavalla ravitsemus vaikuttaa suoritukseen. Sillä, löytääkö nuori liikunnasta itselleen tärkeitä merkityksiä, voikin olla ratkaiseva rooli liikuntaharrastuksen ylläpitämisessä (12). Ja sillä, mitä parempi ymmärrys meillä on niistä tekijöistä, jotka ohjaavat päivittäisiä valintojamme, sitä paremmin kykenemme kehittämään sellaisia ohjelmia ja interventioita, joilla terveyskäyttäytymiseen voidaan vaikuttaa (13). 
Vaikuttavien interventioiden kehittäminen edellyttää myös toteutettujen ohjelmien arvioimista. Suuri osa tehdystä työstä menee kuitenkin hukkaan, jos käyttäytymisenmuutosohjelmia arvioitaessa keskitytään vain lopputulemiin pyrkimättä ymmärtämään, mitä interventioissa tapahtuu (14). Se, että kohderyhmässä havaitaan muutos, ei vielä kerro, tuottiko muutoksen itse ohjelma vai jokin ohjelman ulkopuolinen tekijä. Satunnaistettuja ja kontrolloituja koeasetelmiakin voitaisiin entisestään parantaa käyttämällä monimenetelmällistä tutkimusotetta. Laadullisen tutkimuksen avulla voidaan selvittää esimerkiksi tilannetekijöitä, kokemuksia ohjelmasta, keskeisten viestien ymmärrystä sekä yksilöllisiä esteitä ja kannustimia muutokselle $(15,16)$.

Laadullisten menetelmien potentiaali interventioiden suunnittelulle ja arvioinneille on toki jo tunnistettu (17). Niiden laaja kirjo tarjoaa kuitenkin paljon mahdollisuuksia hyödyntää laadullisia aineistoja nykyistä paremmin ja monipuolisemmin. Aineistojen keruussa voitaisiin haastattelujen ja fokusryhmien ohella käyttää esimerkiksi päiväkirjoja, valokuvia, videoita ja etnografisia menetelmiä. Laadullisen analyysin keinoin voidaan myös paneutua moniin erilaisiin asioihin. Aineistosta voidaan erotella keskeisiä teemoja, joita kvantifioimalla on mahdollista tunnistaa yleisempiä profiileja ja malleja. Niitä tarkastelemalla voidaan esimerkiksi havaita, että osallistujien asettamat tavoitteet ovat laadullisesti erilaisia eivätkä siksi tue uudenlaisten tottumusten omaksumista yhtä hyvin (15) - tai että osallistujat ovat ymmärtäneet joitakin keskeisiä viestejä eri tavalla kuin on tarkoitettu (16). Paneutumalla niihin kehyksiin, diskursseihin ja tulkintarepertuaareihin, joita osallistujat puheessaan käyttävät, on puolestaan mahdollista valottaa esimerkiksi sellaisia arvoristiriitoja, joihin joudumme ottamaan kantaa silloin, kun teemme terveyteemme vaikuttavia päivittäisiä valintoja (18).

Lupaava laadullinen menetelmä ohjelmien arviointiin on avaintapahtuma-analyysi, jota on jo 1950-luvulla käytetty erottelemaan toisaalta hyvään ja toisaalta heikkoon suoritukseen liittyviä tekijöitä ja käyttäytymismalleja (19). Sitä voidaan soveltaa interventioiden prosessiarvioinnissa esimerkiksi tunnistamalla ja luokittelemalla sekä interventioryhmään että verrokkiryhmään kuuluvien vastaajien puheesta sellaisia tekijöitä, joiden he kuvaavat olleen ratkaisevia oman käyttäytymisensä muutoksessa. Tällä tavoin on mahdollista hahmottaa, millaiset avaintapahtumat ovat yhteisiä kummassakin ryhmässä ja millaiset tyypillisiä vain interventioryhmässä - tai havaita, että muutosta on edesauttanut pelkkä kyselyyn vastaaminen tai mittaukseen osallistuminen. Avaintapahtuma-analyysia on työssäni käytetty ensimmäistä kertaa liikuntaintervention prosessiarviointiin. (20.)

Väitöskirjassani olen lähestynyt käyttäytymisen muutosta terveyden edistämisen perspektiivistä käsin. Tutkimukseni keskiössä oli liikunnan lisääminen lukiolaisten ja ammattiin opiskelevien nuorten keskuudessa. Tarkastelin aihetta laadullisesti kilpailukirjoitus- ja haastatteluaineiston pohjalta keskittyen niihin merkitysulottuvuuksiin, jotka tunnistin erityisen tärkeiksi nuorten kuvatessa oman liikkumisensa lisääntymistä $(20$, 21, 22). Tutkimukseni tuloksia voidaan käyttää käyttäytymistieteellisten teorioiden edelleenkehittämisessä valottamaan nuorten liikunnan muutoksiin liittyviä motivaatiotekijöitä ja pystyvyyden tunteen muodostumista. Lisäksi työ havainnollistaa niitä merkityssäikeitä, joilla terveysviestinnän sisältöjä voidaan monipuolistaa ja rikastuttaa, kun vähän liikkuvia nuoria halutaan innostaa liikunnan pariin.

\section{LÄHTEET}

1. McLeroy KR, Bibeau D, Steckler A, ym. An Ecological Perspective on Health Promotion Programs. Health Educ Q 1988;15(4):351-377. doi: $10.1177 / 109019818801500401$

2. Stokols D. Translating Social Ecological Theory into Guidelines for Community Health Promotion. Am J Health Promot 1996;10(4): 282-298.

doi: 10.4278/0890-1171-10.4.282

3. Hankonen N, Absetz P, Araújo-Soares V. Changing activity behaviors in vocational school students: The stepwise development and optimized content of the 'Let's Move it' intervention. Health Psychol Behav Med 2020;8(1):440-460.

https://doi.org/10.1080/21642850.2020.1813036

4. Lintunen T. Liikunnan psykologiaa. Kirjassa: Sinikallio S. (toim.) Terveyden psykologia. Jyväskylä: PS-kustannus; 2019, 305-314.

5. Michie S, van Stralen MM, West R. The behaviour change wheel: A new method for characterising and designing behaviour change interventions. Implement Sci 2011;6(1):42. doi: Artn 42 10.1186/1748-5908-6-42 
6. Absetz P, Hankonen N. Miten auttaa potilaita omaksumaan ja ylläpitämään terveellisiä elämäntapoja? Duodecim 2017;133:53-59.

7. Mutschler C, Naccarato E, Rouse J, ym. Realistinformed review of motivational interviewing for adolescent health behaviors. Syst Rev 2018;7 doi: 10.1186/s13643-018-0767-9

8. Haukkala A, Hankonen N, Konttinen H. Sosiaalipsykologia terveyskäyttäytymisen tutkimuksessa. Psykologia 47(5-6):396-409.

9. Reynolds KJ, Branscombe NR, Subašić E, Willis, L. Changing Behavior Using Social Identity Processes. Kirjassa: Hagger MS, Cameron LD, Hamilton K, Hankonen N, Lintunen T. (toim.) Handbook of Behavior Change. Cambridge: Cambridge University Press; 2020, 225-236.

10. Shepperd JA, Rothman AJ, Klein WMP. Using self- and identity-regulation to promote health: Promises and challenges. Self Identity 2011;10(3):407-416. doi: 10.1080/15298868.2011.577198

11. Koski P. Physical Activity Relationship (Par). Int Rev Sociol Sport 2008;43(2):151-163. doi: $10.1177 / 1012690208095374$

12. Koski P, Tähtinen J. Liikunnan merkitykset nuoruudessa. Nuorisotutkimus 2005;23(1):3-21.

13. Yzer M. The Integrative Model of Behavioral Prediction as a Tool for Designing Health Messages. Kirjassa: Cho H. (toim.) Health Communication Message Design: Theory and Practice. Thousand Oaks, CA: SAGE; 2012, 21-40.

14. Deaton A, Cartwright N. Understanding and misunderstanding randomized controlled trials. Soc Sci Med 2018;210:2-21. doi: 10.1016/j.socscimed.2017.12.005

15. Gardner B, Sheals K, Wardle J, ym. Putting habit into practice, and practice into habit: a process evaluation and exploration of the acceptability of a habit-based dietary behaviour change intervention. Int J Behav Nutr Phys Act 2014;11. doi: 10.1186/s12966-014-0135-7

16. Palsola M, Renko E, Kostamo K, ym. Thematic analysis of acceptability and fidelity of engagement for behaviour change interventions: The Let's Move It intervention interview study. Br J Health Psychol 2020;25(3):772-789. doi:10.1111/bjhp.12433
17. Moore GF, Audrey S, Barker M, ym. Process evaluation of complex interventions: Medical Research Council guidance. Bmj-Br Med J $2015 ; 350$. doi: ARTN h1258 10.1136/bmj.h1258

18. Pajari PM, Jallinoja P, Absetz P. Negotiation over self-control and activity: An analysis of balancing in the repertoires of Finnish healthy lifestyles. Soc Sci Med 2006;62(10):2601-2611. doi: 10.1016/j.socscimed.2005.11.005

19. Flanagan JC. The critical incident technique. Psychol Bull 1954;51(4):327-358. doi: $10.1037 / \mathrm{h} 0061470$

20. Kostamo K, Jallinoja P, Vesala KM, ym. Using the critical incident technique for qualitative process evaluation of interventions: The example of the “Let's Move It" trial. Soc Sci Med 2019;232: 389-397. doi: 10.1016/j.socscimed.2019.05.014

21. Kostamo K, Vesala KM, Hankonen N. Leikistä harrastukseen, hyötyyn ja pelailuun: liikunnan merkitysten muutokset nuorten kilpakirjoituksissa. Psykologia 2017;52(1):23-37.

22. Kostamo K, Vesala KM, Hankonen N. What triggers changes in adolescents' physical activity? Analysis of critical incidents during childhood and youth in student writings. Psychol Sport Exerc 2019;45:101564.

doi: 10.1016/j.psychsport.2019.101564

\section{Katri Kostamo \\ VTT, tutkijatobtori \\ Helsingin yliopisto \\ Valtiotieteellinen tiedekunta, sosiaalipsykologian tieteenala}

Valtiotieteiden maisteri Katri Kostamon sosiaalipsykologian väitöskirja "Hyöty liikuntaan kannustavana, arkiliikunta hyötyjä tuovana: Keskiasteen opiskelijoiden tulkintoja liikkumisensa lisääntymisestä" tarkastettiin Helsingin yliopistossa 16.6.2020. Vastaväittäjänä toimi professori Pasi Koski Turun yliopistosta ja kustoksena professori Inga Jasinskaja-Lahti Helsingin yliopistosta. 